\title{
Effect of gaseous carbon on the carbothermal reduction and nitridation of alumina under a flow of nitrogen
}

\author{
Woo-Sik JUNG ${ }^{\dagger}$ \\ School of Display and Chemical Engineering, College of Engineering, Yeungnam University, Gyongsan 712-749, Korea
}

\begin{abstract}
The carbothermal reduction and nitridation (CRN) of $\alpha$-alumina $\left(\alpha-\mathrm{Al}_{2} \mathrm{O}_{3}\right)$ to aluminum nitride (AIN) with gaseous carbon under a flow of nitrogen was investigated by $\mathrm{X}$-ray diffraction and ${ }^{27} \mathrm{Al}$ magic-angle spinning nuclear magnetic resonance (NMR) spectroscopy. The mixture of $\alpha-\mathrm{Al}_{2} \mathrm{O}_{3}$ and gaseous carbon was obtained by the reaction of aluminum sulfide ( $\left.\mathrm{Al}_{2} \mathrm{~S}_{3}\right)$ with carbon monoxide (CO). The AIN formation commenced at $1100^{\circ} \mathrm{C}$, which is the lowest temperature reported for AIN formation by the CRN reaction. The involvement of gaseous carbon in the CRN reaction, which has not previously been reported in the CRN reaction, greatly reduced the nitridation temperature of $\alpha-\mathrm{Al}_{2} \mathrm{O}_{3}$.
\end{abstract}

(C2009 The Ceramic Society of Japan. All rights reserved.

Key-words : Aluminum nitride, Alumina, Gaseous carbon, Aluminum sulfide, Carbothermal reduction

[Received May 12, 2009; Accepted July 16, 2009]

\section{Introduction}

The AlN has many attractive thermomechanical and electronic properties, such as excellent thermal conductivity, high electrical resistivity, high mechanical strength, and high melting point. ${ }^{1)}$ The carbothermal reduction and nitridation (CRN) method is one of the most useful methods to synthesize AlN powders. ${ }^{2}$ The $\mathrm{CRN}$ reaction is expressed as follows:

$$
\mathrm{Al}_{2} \mathrm{O}_{3}(\mathrm{~s})+3 \mathrm{C}+\mathrm{N}_{2}(\mathrm{~g}) \rightarrow 2 \mathrm{AlN}(\mathrm{s})+3 \mathrm{CO}(\mathrm{g})
$$

Until now, all carbon sources used in the CRN method have been solid-state. ${ }^{3)}$ In our previous paper, ${ }^{4)}$ we showed that the reaction of $\mathrm{Al}_{2} \mathrm{~S}_{3}$ with $\mathrm{CO}$ afforded a mixture of $\alpha-\mathrm{Al}_{2} \mathrm{O}_{3}$ and graphene sheets. The formation of the graphene sheets indicated that gaseous carbon was evolved during the reaction of $\mathrm{Al}_{2} \mathrm{~S}_{3}$ with $\mathrm{CO}$. If the gaseous carbon acts as a carbon source in Eq. (1), the nitridation temperature of $\mathrm{Al}_{2} \mathrm{O}_{3}$ will be greatly lowered. In this report, we investigated the effect of the gaseous carbon on the CRN reaction of $\mathrm{Al}_{2} \mathrm{O}_{3}$ through calcination of $\mathrm{Al}_{2} \mathrm{~S}_{3}$ under a mixed gas flow of $\mathrm{CO}$ and $\mathrm{N}_{2}$.

\section{Experimental procedure}

The compound $\mathrm{Al}_{2} \mathrm{~S}_{3}$ powder used in this study is commercially available as granules (Aldrich Chemical, 98\%) and was ground to obtain a fine powder with a diameter of $\leq 0.125 \mathrm{~mm}$ $(-120$ mesh) before its calcination. The powders in an alumina crucible were set in an alumina tube with an inner diameter of $36 \mathrm{~mm}$ and heated at a rate of $5^{\circ} \mathrm{C} / \mathrm{min}$ to the reaction temperature $\left(1000-1300^{\circ} \mathrm{C}\right)$ in a flowing gas mixture $(200 \mathrm{ml} / \mathrm{min})$ of $\mathrm{CO}$ and $\mathrm{N}_{2}$. The duration time, unless otherwise stated, was $10 \mathrm{~h}$. The as-synthesized products were characterized by powder Xray diffraction (XRD) with a PANalytical X'Pert PRO MPD Xray diffractometer with $\mathrm{Cu} K \alpha$ radiation operating at $40 \mathrm{kV}$ and $30 \mathrm{~mA}$ and by ${ }^{27} \mathrm{Al}$ magic-angle spinning (MAS) nuclear magnetic resonance (NMR) with a Unity INOVA 600 spectrometer (Varian Inc.). High-resolution ${ }^{27}$ Al MAS NMR spectra were acquired at ambient temperature with a radio frequency of

Corresponding author: W.-S. Jung; E-mail: wsjung @ yu.ac.kr
156.3 MHz. The samples were spun at $18 \mathrm{kHz}$, and excitation pulse lengths of $0.5 \mu$ s and pulse delay times of $3 \mathrm{~s}$ were used. The chemical shifts $(\delta)$ were referenced to $1 \mathrm{M}$ aqueous $\mathrm{AlCl}_{3}$ solution. A transmission electron microscopy (TEM) image was recorded on a Philips CM 200 STEM (working at $200 \mathrm{kV}$ ) equipped with energy dispersive X-ray spectroscopy (EDXS).

\section{Results and discussion}

The compound $\mathrm{Al}_{2} \mathrm{~S}_{3}$ is known to form four polymorphs: a hexagonal $\alpha$-form, a related hexagonal $\beta$-form that has a defect wurtzite-type structure, a $\gamma$-form having the corundum-type structure, and a high-pressure tetragonal polymorph with a defect spinel structure. ${ }^{5)}$ The coordination of $\mathrm{Al}$ in the $\alpha$ - and $\beta$-forms is tetrahedral, while it is octahedral in the corundum type. The XRD pattern of the $\mathrm{Al}_{2} \mathrm{~S}_{3}$ powder used in this work showed that it is a mixture of $\alpha$ - and $\gamma-\mathrm{Al}_{2} \mathrm{~S}_{3}$. The $\mathrm{Al}_{2} \mathrm{~S}_{3}$ powders were calcined at the temperature range $1000-1300^{\circ} \mathrm{C}$ under a mixed gas flow of $1 \mathrm{vol} \% \mathrm{CO} / \mathrm{N}_{2}$ and the products were characterized by XRD patterns. The XRD pattern (Fig. 1(a)) of the powder calcined at $1000^{\circ} \mathrm{C}$ contained no peaks other than those assigned to $\alpha-\mathrm{Al}_{2} \mathrm{O}_{3}$ (JCPDS No. 46-1212) and $\alpha-\mathrm{Al}_{2} \mathrm{~S}_{3}$ (JCPDS No. 471313). In the sample calcined at $1100^{\circ} \mathrm{C}$, the peaks assigned to AlN (JCPDS No. 25-1133), $\alpha-\mathrm{Al}_{2} \mathrm{O}_{3}$, and $\alpha-\mathrm{Al}_{2} \mathrm{~S}_{3}$, were detected, as shown in Fig. 1(b). With increasing the calcination temperature, the peaks assigned to $\alpha-\mathrm{Al}_{2} \mathrm{~S}_{3}$ became weaker and completely disappeared for the samples obtained at temperatures $\geq 1250^{\circ} \mathrm{C}$. On the other hand, the intensities of the peaks assigned to AlN gradually increased as the calcination temperature was increased from 1100 to $1300^{\circ} \mathrm{C}$. As shown in Fig. 1(f), the sample calcined at $1300^{\circ} \mathrm{C}$ was a mixture of AlN and $\alpha$ $\mathrm{Al}_{2} \mathrm{O}_{3}$.

MAS NMR spectroscopy is a powerful probe to characterize solid-state materials, particularly when complex phase mixtures of crystalline and amorphous components are present. The XRD pattern-based assignments of the samples, which were calcined at different reaction temperatures for $10 \mathrm{~h}$ under a flow of $1 \mathrm{vol} \%$ $\mathrm{CO} / \mathrm{N}_{2}$, were confirmed by ${ }^{27} \mathrm{Al}$ MAS NMR spectroscopy. The NMR spectrum (Fig. 2(a)) of the $\mathrm{Al}_{2} \mathrm{~S}_{3}$ precursor, which was quite different from that ${ }^{6)}$ measured at the magnetic field of $6.9 \mathrm{~T}$ 


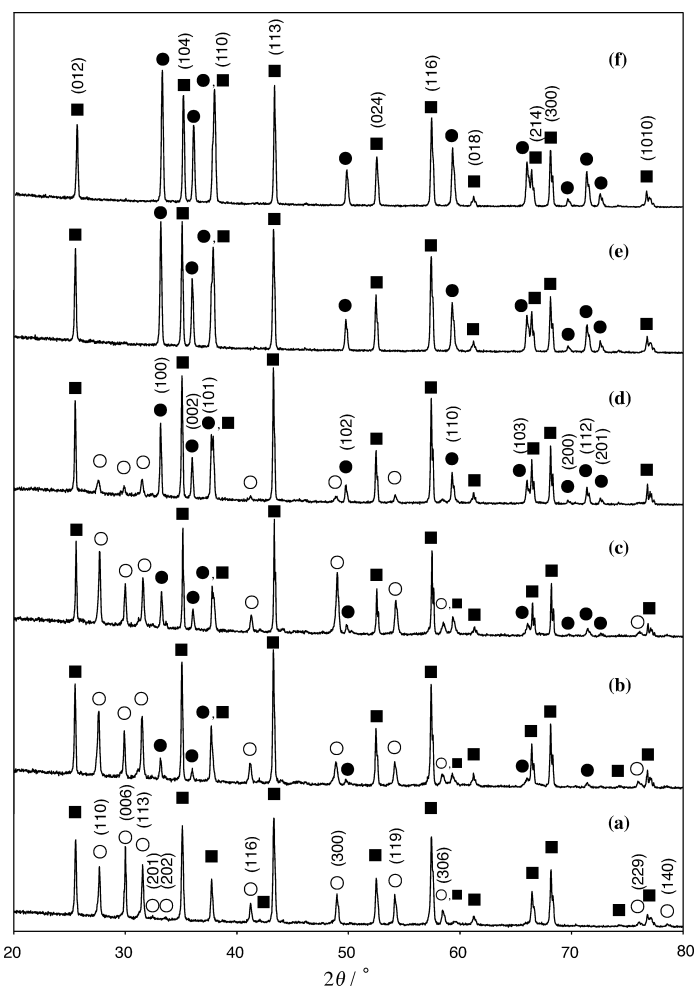

Fig. 1. XRD patterns of samples obtained by calcination of $\mathrm{Al}_{2} \mathrm{~S}_{3}$ powder under a flow of $1 \mathrm{vol} \% \mathrm{CO} / \mathrm{N}_{2}$ at various temperatures for $10 \mathrm{~h}$; (a) $1000^{\circ} \mathrm{C}$, (b) $1100^{\circ} \mathrm{C}$, (c) $1150^{\circ} \mathrm{C}$, (d) $1200^{\circ} \mathrm{C}$, (e) $1250^{\circ} \mathrm{C}$ and (f) $1300^{\circ} \mathrm{C}$. (○) $\mathrm{AlN},(\mathbf{\square}) \alpha-\mathrm{Al}_{2} \mathrm{O}_{3},(\bigcirc) \alpha-\mathrm{Al}_{2} \mathrm{~S}_{3}$.

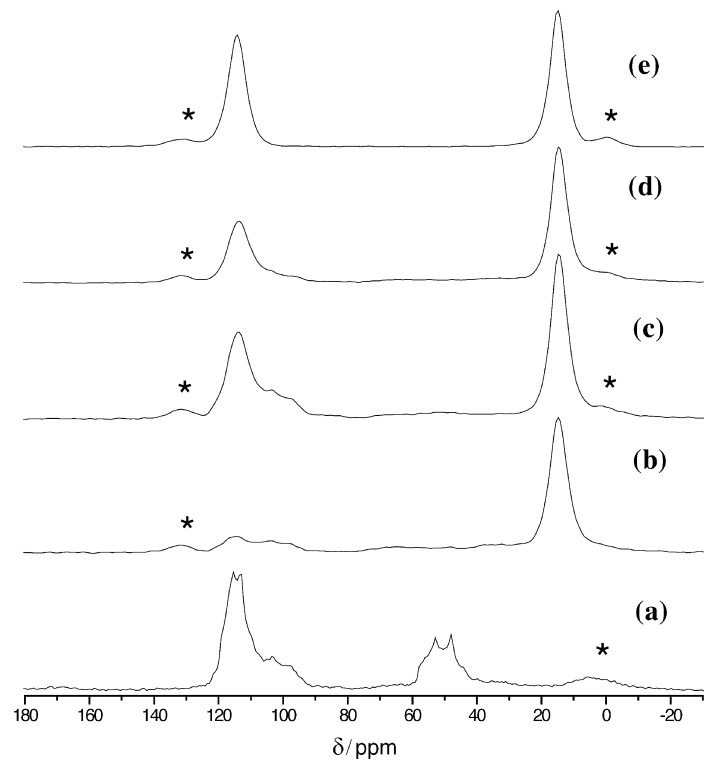

Fig. 2. ${ }^{27} \mathrm{Al}$ MAS NMR spectra of $\mathrm{Al}_{2} \mathrm{~S}_{3}$ powders (a) before and after calcination at (b) 1000 , (c) 1150 , (d) 1200 and (e) $1300^{\circ} \mathrm{C}$ for $10 \mathrm{~h}$ under a flow of $1 \mathrm{vol} \% \mathrm{CO} / \mathrm{N}_{2}$. The spinning side bands are marked by asterisks.

and spinning rate of $5 \mathrm{kHz}$, exhibited two powder-patterned peaks centered at ca. $\delta 50$ and $110 \mathrm{ppm}$, each of which is assigned to six-coordinated $\left(\mathrm{AlS}_{6}\right)$ and four-coordinated $\left(\mathrm{AlS}_{4}\right)$ aluminum sites, respectively, considering that the coordination of $\mathrm{Al}$ in the $\gamma$ - and $\alpha-\mathrm{Al}_{2} \mathrm{~S}_{3}$ is octahedral and tetrahedral, respec-

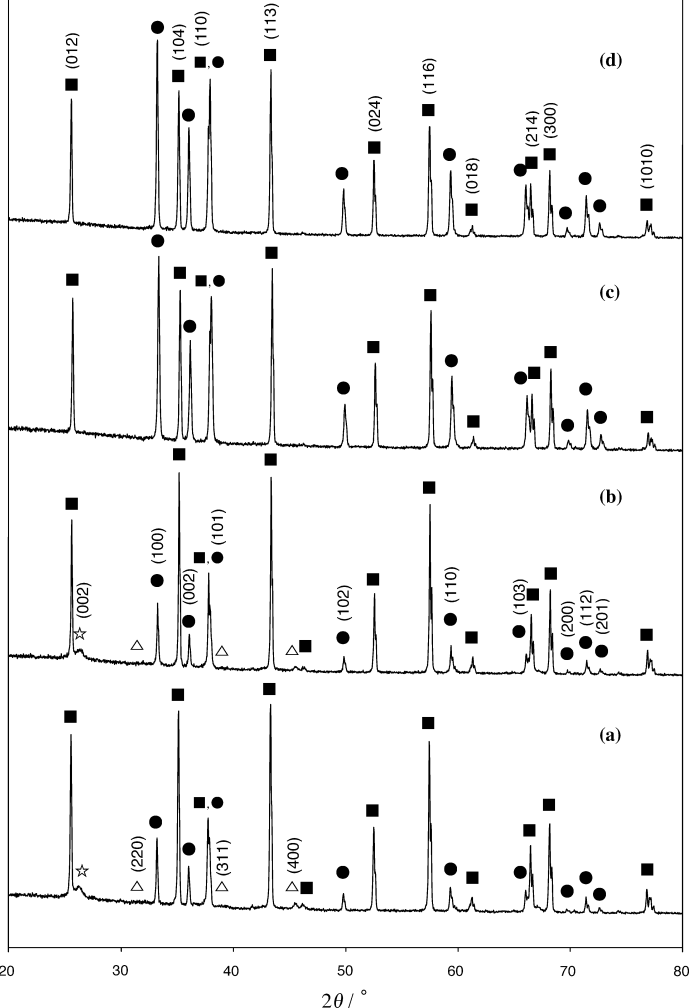

Fig. 3. XRD patterns of samples obtained by calcination of $\mathrm{Al}_{2} \mathrm{~S}_{3}$ powder at $1300^{\circ} \mathrm{C}$ for $10 \mathrm{~h}$ under a flow of $10 \mathrm{vol} \% \mathrm{CO} / \mathrm{N}_{2}$ (a) before and after further calcination at (b) 1300 , (c) 1400 and (d) $1500^{\circ} \mathrm{C}$ for $5 \mathrm{~h}$ under a flow of $\mathrm{N}_{2}$. ( $) \mathrm{AlN},(\boldsymbol{\square}) \alpha-\mathrm{Al}_{2} \mathrm{O}_{3},(\triangle) \gamma$-AlON, (泞) graphene sheets.

tively. In the sample calcined at $1000^{\circ} \mathrm{C}$ an intense peak (at $\delta$ $15 \mathrm{ppm}$ ) assigned to $\alpha-\mathrm{Al}_{2} \mathrm{O}_{3}$ was detected together with a weak powder-patterned peak of $\alpha-\mathrm{Al}_{2} \mathrm{~S}_{3}$. The peak at $\delta 114 \mathrm{ppm}$ observed in Figs. 2(c) to (e) is assigned to AlN. ${ }^{7)}$ With increasing the calcination temperature, the peak assigned to $\alpha-\mathrm{Al}_{2} \mathrm{~S}_{3}$ became weaker. As shown in Fig. 2(e), the peak assigned to $\alpha-\mathrm{Al}_{2} \mathrm{~S}_{3}$ completely disappeared for the sample calcined at $1300^{\circ} \mathrm{C}$.

As aforementioned, the AlN formation by the $\mathrm{CRN}$ reaction of $\alpha-\mathrm{Al}_{2} \mathrm{O}_{3}$ commenced at $1100^{\circ} \mathrm{C}$, which is the lowest temperature reported for AlN formation by the $\mathrm{CRN}$ reaction. In our previous paper ${ }^{4)}$ we showed that the reaction of $\mathrm{Al}_{2} \mathrm{~S}_{3}$ with $\mathrm{CO}$ afforded a mixture of $\alpha-\mathrm{Al}_{2} \mathrm{O}_{3}$ and graphene sheets and that not all evolved gaseous carbon crystallized in the graphene sheets. The formation of the graphene sheets indicated that gaseous carbon was evolved during the reaction of $\mathrm{Al}_{2} \mathrm{~S}_{3}$ with $\mathrm{CO}$. The reduced AIN formation temperature was attributed to the involvement of the gaseous carbon in the $\mathrm{CRN}$ reaction of Eq. (1). It might be proposed, therefore, that the formation reaction of AlN by calcining $\mathrm{Al}_{2} \mathrm{~S}_{3}$ under a mixed gas flow of $\mathrm{CO}$ and $\mathrm{N}_{2}$ consists of the following two consecutive reactions I and II:

$$
\begin{array}{r}
\text { Reaction I: } \begin{array}{r}
\mathrm{Al}_{2} \mathrm{~S}_{3}(\mathrm{~s})+3 \mathrm{CO}(\mathrm{g}) \rightarrow \\
\alpha-\mathrm{Al}_{2} \mathrm{O}_{3}(\mathrm{~s})+3 \mathrm{C}(\mathrm{g}, \mathrm{s})+3 \mathrm{~S}(\mathrm{~g})
\end{array} \\
\text { Reaction II: } \alpha-\mathrm{Al}_{2} \mathrm{O}_{3}(\mathrm{~s})+3 \mathrm{C}(\mathrm{g}, \mathrm{s})+\mathrm{N}_{2}(\mathrm{~g}) \rightarrow \\
2 \mathrm{AlN}(\mathrm{s})+3 \mathrm{CO}(\mathrm{g})
\end{array}
$$

The proposed reaction mechanism is supported by the following findings. First, the calcination of $\mathrm{Al}_{2} \mathrm{~S}_{3}$ under a mixed gas flow of $\mathrm{CO}$ and argon afforded graphene sheets (corresponding to $\mathrm{C}(\mathrm{s})$ in reaction I) and $\alpha-\mathrm{Al}_{2} \mathrm{O}_{3}{ }^{4)}$ but did not afford AlN because of 

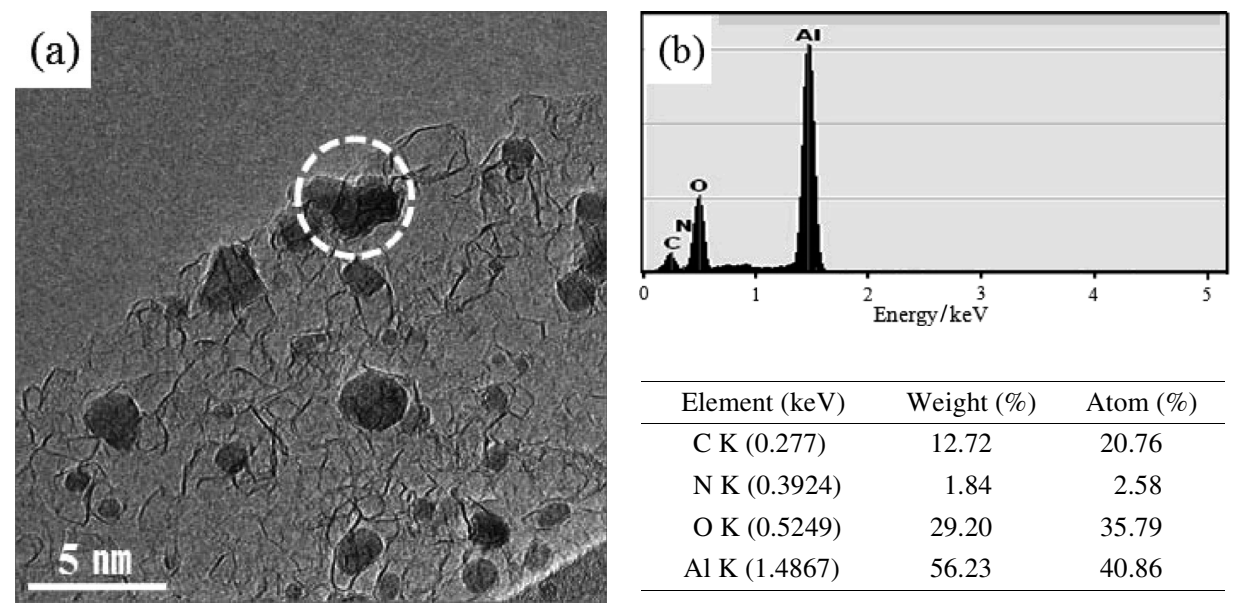

Fig. 4. (a) TEM image of the sample obtained by calcination of $\mathrm{Al}_{2} \mathrm{~S}_{3}$ powder at $1300^{\circ} \mathrm{C}$ for $10 \mathrm{~h}$ under a flow of $10 \mathrm{vol} \% \mathrm{CO} / \mathrm{N}_{2}$ and (b) EDX spectrum of the portion designated by the dotted circle in Fig. 4(a).

no occurrence of reaction II. Second, a part of the gaseous sulfur liberated in reaction I was deposited on the inner wall of the downstream end of the alumina tube. Third, the calcination of $\mathrm{Al}_{2} \mathrm{~S}_{3}$ under a flow of $\mathrm{N}_{2}$ did not afford $\mathrm{AlN}$ because of no occurrence of reaction $\mathrm{I}$.

The possibility that $\alpha-\mathrm{Al}_{2} \mathrm{O}_{3}$ reacted with solid-state carbon (graphene sheets) at the temperatures $\leq 1300^{\circ} \mathrm{C}$ can be ruled out by the following findings. We prepared the sample obtained by calcining $\mathrm{Al}_{2} \mathrm{~S}_{3}$ powder at $1300^{\circ} \mathrm{C}$ for $10 \mathrm{~h}$ under a mixed gas flow of $10 \mathrm{vol} \% \mathrm{CO} / \mathrm{N}_{2}$ and measured its XRD pattern and TEM image. The XRD pattern (Fig. 3(a)), showing that the sample was a mixture of $\alpha-\mathrm{Al}_{2} \mathrm{O}_{3}, \mathrm{AlN}$, graphene sheets, and $\gamma$-AlON (JCPDS No. 80-2173), was considerably different from that (Fig. 1(f)) of the sample calcined at $1300^{\circ} \mathrm{C}$ for $10 \mathrm{~h}$ under a flow of $1 \mathrm{vol} \% \mathrm{CO} / \mathrm{N}_{2}$ because of the retardation effect of $\mathrm{CO}$ in reaction II. The CRN reaction became more retarded with increasing $\mathrm{CO}$ content in the mixed gas. ${ }^{8)}$ The $\gamma$-AlON phase was formed by the reaction of AlN with $\alpha-\mathrm{Al}_{2} \mathrm{O}_{3}$ and its formation temperature was ca. $300^{\circ} \mathrm{C}$ lower than that in the modified CRN reaction. ${ }^{9)}$ The TEM image (Fig. 4(a)) of the sample showed rippled graphene sheets and nanosized ceramic particles. The sample's energy dispersive X-ray (EDX) spectrum (Fig. 4(b)) exhibited the existence of elements such as carbon, aluminum, nitrogen, and oxygen. The high atomic\% of carbon strongly supported the existence of graphene sheets in the sample. The sample calcined at $1300^{\circ} \mathrm{C}$ for $10 \mathrm{~h}$ under a flow of $10 \mathrm{vol} \% \mathrm{CO} / \mathrm{N}_{2}$ was further calcined at $1200,1300,1400$, and $1500^{\circ} \mathrm{C}$ for $5 \mathrm{~h}$ under a flow of $\mathrm{N}_{2}$. The XRD patterns of the samples obtained are shown in Figs. 3(b)-(d). The XRD patterns of the samples calcined at 1200 and $1300^{\circ} \mathrm{C}$ were the same as that (Fig. 3(a)) before the further calcination, indicating that $\alpha-\mathrm{Al}_{2} \mathrm{O}_{3}$ did not react with the graphene sheets at 1200 and $1300^{\circ} \mathrm{C}$. As shown in Fig. 3(c), the calcination at $1400^{\circ} \mathrm{C}$ afforded a mixture of $\alpha-\mathrm{Al}_{2} \mathrm{O}_{3}$ and $\mathrm{AlN}$. The peaks assigned to AlN in Fig. 3(c) were more intense than those in Fig. 3(a) and the peaks assigned to graphene sheets disappeared, indicating that $\alpha-\mathrm{Al}_{2} \mathrm{O}_{3}$ reacted with graphene sheets at $1400^{\circ} \mathrm{C}$. The nitridation temperature of $1400^{\circ} \mathrm{C}$ was at least $100^{\circ} \mathrm{C}$ lower than that ${ }^{2), 3)}$ in the conventional CRN method in which $\alpha-\mathrm{Al}_{2} \mathrm{O}_{3}$ powder is mechanically mixed with carbon sources. This is caused by the mixing homogeneity of $\alpha-\mathrm{Al}_{2} \mathrm{O}_{3}$ and carbon (graphene sheets). The XRD pattern (Fig. 3(d)) of the sample calcined at $1500^{\circ} \mathrm{C}$ was almost the same as that of Fig. $3(\mathrm{c})$. These results lead to the conclusion that $\alpha-\mathrm{Al}_{2} \mathrm{O}_{3}$ did not react with the graphene sheets at the temperatures $\leq 1300^{\circ} \mathrm{C}$. Therefore, the AlN formation at the temperatures $\leq 1300^{\circ} \mathrm{C}$ under a flow of $1 \mathrm{vol} \% \mathrm{CO} / \mathrm{N}_{2}$ was caused by the $\mathrm{CRN}$ reaction of $\alpha-\mathrm{Al}_{2} \mathrm{O}_{3}$ with gaseous carbon. This is the first report of the involvement of gaseous carbon in the CRN reaction of Eq. (1). The incomplete conversion of $\mathrm{Al}_{2} \mathrm{~S}_{3}$ to $\mathrm{AlN}$ under a flow of $1 \mathrm{vol} \%$ $\mathrm{CO} / \mathrm{N}_{2}$ was caused by the partial exhaust of gaseous carbon evolved in reaction $\mathrm{I}$.

If gaseous carbon is used instead of solid-state carbon in the CRN reaction, the nitridation reaction temperature will be much lowered and the processes such as the intimate mixing of $\mathrm{Al}_{2} \mathrm{O}_{3}$ with carbon and removal of unreacted carbon will be unnecessary.

\section{Conclusion}

The gaseous carbon, which was produced by the reaction of $\mathrm{Al}_{2} \mathrm{~S}_{3}$ with $\mathrm{CO}$, reacted with $\alpha-\mathrm{Al}_{2} \mathrm{O}_{3}$ under a flow of $\mathrm{N}_{2}$ to afford AlN. The AlN formation commenced at $1100^{\circ} \mathrm{C}$, which is the lowest temperature reported for AlN formation by the CRN reaction. This is the first report of the involvement of gaseous carbon in the CRN reaction. This work has demonstrated that the use of gaseous carbon in the $\mathrm{CRN}$ reaction greatly lowers the nitridation temperature of $\mathrm{Al}_{2} \mathrm{O}_{3}$.

Acknowledgement This work was supported by the National Center for Nanomaterials Technology through Yeungnam University in 2008 . The ${ }^{27} \mathrm{Al}$ MAS NMR spectra were recorded at the Analysis Research Division, Daegu Center, Korea Basic Science Institute.

\section{References}

1) L. M. Sheppard, Am. Ceram. Soc. Bull., 69, 1801-1812 (1990).

2) G. Selvadruray and L. Sheet, Mater. Sci. Technol., 9, 463-473 (1993).

3) Y. W. Cho and J. A. Charles, Mater. Sci. Technol., 7, 495-504 (1991).

4) C. D. Kim, B.-K. Min and W.-S. Jung, Carbon, 47, 1610-1612 (2009).

5) P. C. Donohue, J. Solid State Chem., 2, 6-8 (1970).

6) W.-S. Jung and S.-K. Ahn, Mater. Lett., 43, 53-56 (2000).

7) R. Dupree, M. H. Lewis and M. E. Smith, J. Appl. Crystallogr., 21, 109-116 (1998).

8) H. U. Joo and W.-S. Jung, J. Mater. Proc. Technol., 204, 498501 (2008).

9) H. U. Joo, S.-A. Chae and W.-S. Jung, Diam. Relat. Mater., 17, 352-355 (2008). 